\title{
Breathing pattern during bronchial challenge in humans
}

\author{
N.E.L. Meessen*, C.P.M. van der Grinten**, S.C.M. Luijendijk**, H.Th.M. Folgering*
}

Breathing pattern during bronchial challenge in humans. N.E.L. Meessen, C.P.M. van der Grinten, S.C.M. Luijendijk, H.Th.M. Folgering. (CERS Journals Ltd 1997.

ABSTRACT: Increases in minute ventilation $\left(V^{\prime} E\right)$ have been observed during exacerbations of asthma and in response to administration of histamine. However, it is not yet clear how the breathing pattern is affected, and whether the increase in $V^{\prime} \mathrm{E}$ is found in general.

In the present study, the effects of inhalation of histamine on respiratory frequency $(f \mathrm{R})$, tidal volume $(V \mathrm{~T}), V^{\prime} \mathrm{E}$, and on functional residual capacity (FRC) were evaluated in 63 humans. Forty four subjects were hyperresponsive (BHR+). In each of these subjects, the doses of histamine applied for the present study (mean $3.5 \mathrm{mg} \cdot \mathrm{mL}^{-1}$ ) caused a decrease in forced expiratory volume in one second (FEV1) that was greater than $20 \%$ of the control value. The dose of histamine applied in the 19 nonhyperresponsive subjects (BHR-) was substantially larger $(8.0$ $\mathrm{mg} \cdot \mathrm{mL}^{-1}$ ) whilst for this dose the decrease in FEV1 was less than $20 \%$ of control value.

After histamine, $f \mathrm{R}$ was significantly increased in both subgroups of subjects, $B H R+$ and BHR-. The increase in $V^{\prime} \mathrm{E}$ was significant in BHR-but not significant in $\mathrm{BHR}+$. In general, the changes in $V^{\prime} \mathrm{E}, f \mathrm{R}$ and $V_{\mathrm{T}}$ were not uniform; comparable numbers of subjects responded with increases $(n=33)$ and decreases $(n=30)$ in $V^{\prime}$ E. For $f \mathrm{R} 40$ subjects responded with an increase and 23 with a decrease, and for $V T$ these numbers were 26 and 37, respectively. The increase in FRC after histamine was significantly larger in BHR+ subjects than in BHR-.

These findings may be interpreted to indicate that different mechanisms with opposite effects may be operating simultaneously, e.g. excitation of central inspiratory activity by stimulation of rapidly-adapting pulmonary stretch receptors, which will promote increases in respiratory frequency, tidal volume and minute ventilation, and bronchoconstriction with increased airway resistance, which will promote decreases in these parameters. As a consequence, depending on the net result of these opposite contributions to, e.g. minute ventilation, administration of histamine will cause an increase in minute ventilation in one subject and a decrease in another.

Eur Respir J 1997; 10: 1059-1063.

Bronchoconstriction and hyperventilation occur during exacerbations of asthma. Generally, arterial carbon dioxide tension $\left(\mathrm{Pa}_{\mathrm{a}} \mathrm{CO}_{2}\right)$ does not change, or even decreases during exacerbations of asthma, indicating that ventilation must have increased $[1,2]$. It has been known for years that patients with asthma hyperventilate when acutely ill [3-5]. It has also been found that minute ventilation $\left(V^{\prime} \mathrm{E}\right)$ increases in response to progressive methacholine-induced and histamine-induced bronchoconstriction [5-9]. Other studies, however, have indicated that inhaled histamine or methacholine may result in a rapid, sometimes shallow, breathing pattern [10], or that the breathing pattern is not changed in response to histamine or methacholine $[11,12]$. Thus, results on ventilatory responses to induced bronchoconstriction reported in the literature are not consistent. STROMBERG and Gustafsson [13] found that, during a histamine challenge, 4 out of 8 patients responded with an increase in $V^{\prime} \mathrm{E}$, whereas $V^{\prime} \mathrm{E}$ was unchanged or tended to decrease in the remaining patients. These authors suggested that the latter patients were "ventilatory nonresponders".

Recently, it has been shown, in a selected group of
*Dept of Pulmonary Diseases, University Hospital Nijmegen, Dekkerswald, Groesbeek, The Netherlands. **Dept of Pulmonology, University Hospital Maastricht, Maastricht, The Netherlands.

Correspondence: N.E.L. Meessen Dept of Pulmonology University Hospital Maastricht P.O. Box 5800 6202 AZ Maastricht The Netherlands

Keywords: Control of breathing histamine

pulmonary receptors

Received: February 261996 Accepted after revision January 311997 patients with asthma, that during histamine challenge tests changes in breathing pattern occur prior to changes in the forced expiratory volume in one second (FEV1) [14]. This finding suggests that the increase in airway resistance does not play the only role in the change in pattern of breathing, and, furthermore, that vagal airway receptors may be involved by direct stimulation. It is well-known that pulmonary receptors influence the breathing pattern $[15,16]$. The duration of inspiration $(t \mathrm{I})$ is controlled mainly by slowly-adapting stretch receptors (SARs) through the off-switch mechanism, and, at least in part, duration of expiration $(t \mathrm{E})$ is determined by rapidly-adapting stretch receptors (RARs) [17-19]. In a previous study in cats, we found that respiratory frequency $(f R)$ increased significantly $(p<0.01)$ in response to stimulation of RARs by intravenous administration of histamine [20]. During mechanical stimulation of RARs by continuous negative airway pressure, an increase in $f \mathrm{R}$ was also found [21]. RARs can be stimulated by histamine in two ways: mechanically (by bronchoconstriction) and chemically [22-25].

Functional residual capacity (FRC) may increase after 
administration of histamine. This is due to the concomitant bronchoconstriction and/or an increase in end-tidal inspiratory activity (ETIA) [26]. Changes in FRC may indirectly influence the breathing pattern because of the relationship between lung volume and the activity of pulmonary stretch receptors. Furthermore, an increase in FRC may limit the increase in $V \mathrm{~T}$.

It is not yet clear how the breathing pattern changes during exacerbations of asthma and induced bronchoconstriction. The aims of the present study, therefore, were: 1) to evaluate the effects of administration of histamine on the breathing pattern and on FRC in humans; and 2) to evaluate whether the degree of bronchial responsiveness plays a role in histamine-induced changes in $V^{\prime}$ 'E.

\section{Methods}

\section{Subjects}

Sixty three subjects participated in this study. Characteristics of the subjects are presented in table 1. Bronchodilators were withheld for at least $8 \mathrm{~h}$ prior to the study. In a standardized histamine challenge test, the provocative concentration of histamine which caused a fall of $\geq 20 \%$ in FEV1 (PC20) $[27,28]$ was determined. To shorten the duration of the test, the starting concentration of histamine varied depending on the response to an aerosol of saline, and medication requirements [2830]. A histamine concentration of $8 \mathrm{mg} \cdot \mathrm{mL}^{-1}$ was used as the upper limit of the test. Forty four subjects showed bronchial hyperresponsiveness ( $\left.\mathrm{PC}_{20} \leq 8 \mathrm{mg} \cdot \mathrm{mL}^{-1}\right)$ ("BHR+"). The remaining 19 subjects were not hyperresponsive ("BHR-"). Informed consent was obtained from all subjects. The subjects were naive with respect to the scientific goals of the study. The study was approved by the hospital Medical Ethics Committee.

\section{Experimental set-up}

Aerosols were generated by a DeVilbiss 646 jet nebulizer (Devilbiss Co., Somerset, PA, USA. The calibrated output of the nebulizer was $0.13 \mathrm{~mL} \cdot \mathrm{min}^{-1}$. The histamine concentration that was used in the further experi-

Table 1. - Characteristics of subjects

\begin{tabular}{|c|c|c|c|}
\hline & Total & $\mathrm{BHR}+$ & BHR- \\
\hline Subjects $\mathrm{n}$ & 63 & 44 & 19 \\
\hline $\operatorname{Sex} M / F$ & $29 / 34$ & $21 / 23$ & $8 / 11$ \\
\hline Age yrs & $34 \pm 2$ & $35 \pm 2$ & $34 \pm 2$ \\
\hline Height $\mathrm{cm}$ & $173 \pm 1$ & $172 \pm 1$ & $175 \pm 2$ \\
\hline Histamine $\mathrm{mg} \cdot \mathrm{mL}^{-1}$ & $4.8 \pm 0.44$ & $3.5 \pm 0.50$ & $8.0 \pm 0.0 * * *$ \\
\hline $\begin{aligned} \text { FEV1 } \% \text { pred control } \\
\text { histamine }\end{aligned}$ & $\begin{array}{l}92 \pm 2 \\
70 \pm 3 \# \# \#\end{array}$ & $\begin{array}{l}87 \pm 2 \\
60 \pm 2 \# \# \#\end{array}$ & $\begin{array}{l}103 \pm 3 * * * \\
93 \pm 3^{\# \# * * * * *}\end{array}$ \\
\hline
\end{tabular}

Data are presented as absolute number or as mean \pm SEM. \% pred: percentage of predicted value; M: male; F: female; FEV1: forced expiratory volume in one second; BHR+: hyperresponsive; BHR-: nonhyperresponsive. Note that the concentration of histamine administered to the subgroup of subjects with BHR- was about twice that administered to the subgroup of subjects with BHR+. \#\#\#: $\mathrm{p}<0.001$, compared to control values; ***: $\mathrm{p}<0.001$, compared to $\mathrm{BHR}+$ values.

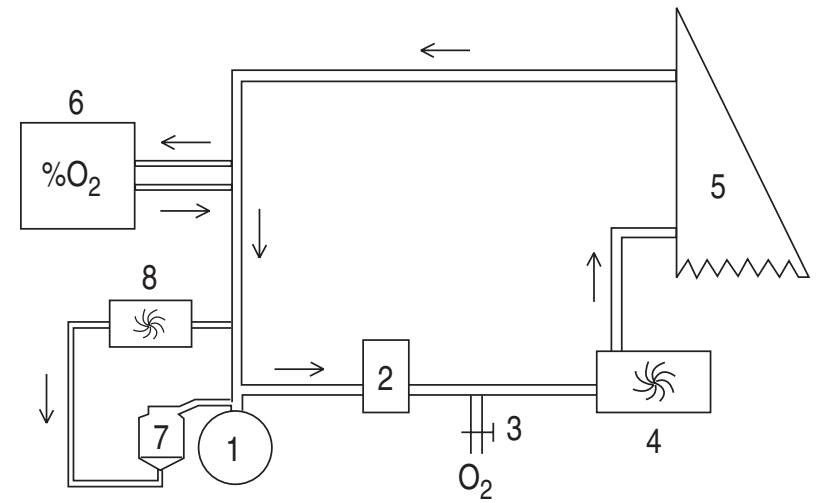

Fig. 1. - Diagram of breathing circuit. 1: subject connected to circuit by mouthpiece; 2 : soda lime; 3 : port for supplying $\mathrm{O}_{2} ; 4$ : blower for bias flow; 5: wedge spirometer; 6: $\mathrm{O}_{2}$ analyser; 7: nebulizer; 8: blower generating flow for aerosol. The dead space of the circuit was $49 \mathrm{~mL}$.

ments depended on the individual result of the histamine challenge protocol. In BHR+ subjects, ventilatory parameters were studied at the PC20 dose. In BHR- subjects, the ventilatory parameters were studied at a histamine dose of $8 \mathrm{mg} \cdot \mathrm{mL}^{-1}$.

FEV1 and FVC were measured by a pneumotachograph (Fukuda Sangyo, Tokyo, Japan). Changes $(\Delta)$ in FRC, $f$ R tidal volume $(V \mathrm{~T})$ and $V^{\prime} \mathrm{E}$ were calculated from the spirograms recorded before and after inhalation of histamine. Two methods were applied to record these spirograms: 1) using a wedge spirometer in a closed breathing circuit; and 2) using respiratory inductive plethysmography (RIP) (Respitrace $\AA$; Respitrace Ca, Ardsley, USA). Values were related to the reference values of the European Respiratory Society [31].

Forty one subjects (29 BHR+ and 12 BHR-) were connected to the closed breathing circuit by a mouthpiece. A blower maintained a constant bias flow in the circuit $\left(120 \mathrm{~L} \cdot \mathrm{min}^{-1}\right)$. Gas was sampled continuously from the circuit for measurement of the oxygen concentration (Taylor Servomex, Sussex, UK), and subsequently fed back into the system (fig. 1). Oxygen was supplied to maintain a constant oxygen concentration (21\%) in the circuit. Exhaled $\mathrm{CO}_{2}$ was absorbed by soda lime. A mismatch between $\mathrm{O}_{2}$ supply and $\mathrm{O}_{2}$ uptake by the subject would cause the baseline of the spirometer signal to drift one way or the other, which would affect the result for $\triangle \mathrm{FRC}$. The shift of the baseline of the spirometer signal $(\Delta V)$ is proportional to the deviation of the $\mathrm{O}_{2}$ concentration $\left(\Delta \mathrm{CO}_{2}\right)$ from $21 \%$. The relationship between $\Delta V$ and $\Delta \mathrm{CO}_{2}$ was determined experimentally by adding a known amount of pure oxygen to the system and reading the corresponding change in $\mathrm{CO}_{2}$. With the help of this relationship, we have corrected the raw data for $\triangle \mathrm{FRC}$ for the aforementioned $\mathrm{CO}_{2}$-related shift of the baseline of the spirometer signal. The inaccuracy of the correction was $\pm 6 \mathrm{~mL}$. This error adds to the overall random error in the determination of $\triangle \mathrm{FRC}$. The DeVilbiss 646 jet nebulizer was connected to the circuit near the mouthpiece (fig. 1).

The remaining subjects (15 BHR+ and 7 BHR-) were connected to the RIP system and via a mouthpiece to the nebulizer. The RIP was used in the direct current (DC)-mode. Volume calibration of the Respitrace was performed with a spirometer (Hospal, Littleton, CO, 
USA), just prior to the administration of the aerosol of histamine, and immediately after the recording had been ended while the subject was still sitting in the same position. If the two calibration factors differed by more than $10 \%$, the measurement was excluded from the study. Thus, for each subject, a conversion factor was calculated from the lung volume changes measured with the spirometer and the associated deflections obtained from the RIP.

The spirograms were recorded with a multichannel X-t recorder (Kip, The Netherlands) for off-line analysis of the changes in $V^{\prime} \mathrm{E}, V \mathrm{~T}, f \mathrm{R}$ and FRC. All subjects were tested in the sitting position, whilst breathing through the mouthpiece with the nose clipped. When the subjects were seated in a relaxed posture, they were asked to remain seated in that way until the end of the recording. Thus, with the co-operation of the subjects, we were able to minimize the impact of postural muscles on the volume changes recorded. To divert their attention from breathing, the subjects were asked to concentrate on a poster placed in front of them.

\section{Experimental protocol}

Recording was started after the subjects had been connected to the mouthpiece. The uninterrupted recording included control breaths, breaths during the period of 2 min of inhalation of histamine, and for at least $1 \mathrm{~min}$ following inhalation of histamine. FEV1 and FVC were measured immediately before this recording, and 1.5 min after inhalation of histamine had been stopped.

\section{Statistical analysis}

From each recording, two sets of values for $f \mathrm{R}, V \mathrm{~T}$, and $V^{\prime} \mathrm{E}$ were calculated from five consecutive control breaths just prior to the inhalation of histamine, and from five consecutive breaths $1 \mathrm{~min}$ after inhalation of histamine, respectively. The $\triangle \mathrm{FRC}$ was calculated from the shift in the baseline of the spirometer signal between these two groups of breaths.

Differences between the results before (control) and after inhalation of histamine, and differences between the results of the two groups (BHR+ and BHR-) were evaluated for statistical significance using the t-test for paired observations and the t-test for unpaired observations, respectively. A p-value of less than 0.05 was considered to be significant.

\section{Results}

The characteristics of the subjects are presented in table 1 . Sex, age and height were not significantly different between BHR+ and BHR-. For BHR+, BHR- and the group as a whole, FEV1 decreased significantly in response to the dose of histamine applied as compared with control values. The mean concentration of histamine administered to $\mathrm{BHR}+\left(3.5 \mathrm{mg} \cdot \mathrm{mL}^{-1}\right)$ was less than half of that administered to BHR- $\left(8.0 \mathrm{mg} \cdot \mathrm{mL}^{-1}\right)$. Nonetheless, the decrease in FEV1 in $\mathrm{BHR}+$ was considerably larger than that in BHR-.
Table 2. - Effects of aerosolized histamine on breathing pattern

\begin{tabular}{llccc}
\hline & & Total & BHR+ & BHR- \\
\hline Subjects n & & 63 & 44 & 19 \\
$V^{\prime}$ 'E L·min & & & \\
& control & $8.1 \pm 0.4$ & $8.3 \pm 0.4$ & $7.8 \pm 0.7$ \\
$f_{\text {R breaths }} \cdot m^{-1}{ }^{-1}$ & histamine & $8.7 \pm 0.4$ & $8.6 \pm 0.5$ & $8.8 \pm 0.8^{\#}$ \\
& control & $16.3 \pm 0.7$ & $17.1 \pm 0.8$ & $14.3 \pm 1.2$ \\
$V$ T mL & histamine & $17.8 \pm 0.8^{\# \# \# \#} 18.6 \pm 1.0^{\#}$ & $15.9 \pm 1.5^{\#}$ \\
& control & $524 \pm 21$ & $496 \pm 19$ & $589 \pm 49^{*}$ \\
$\Delta$ FRC \% pred & histamine & $514 \pm 21$ & $479 \pm 21$ & $595 \pm 46^{*}$ \\
$\Delta$ FRC mL & & $8 \pm 1$ & $9.9 \pm 1.3$ & $4.1 \pm 1.0^{* *}$ \\
& & $256 \pm 31$ & $312 \pm 40$ & $128 \pm 33^{* *}$ \\
\hline
\end{tabular}

Data are presented as mean \pm SEM for all subjects (total), subjects with hyperresponsiveness $(\mathrm{BHR}+)$ and subjects without hyperresponsiveness (BHR-). $\Delta$ : changes relative to control; $V^{\prime} \mathrm{E}$ : minute ventilation; $f \mathrm{R}$ : respiratory frequency; $V \mathrm{~T}$ : tidal volume; FRC: functional residual capacity. *: $\mathrm{p}<0.05$, compared to BHR+; **: $\mathrm{p}<0.01$, compared to BHR+; \#: $<<0.05$ compared to control value; \#\#\#: $\mathrm{p}<0.001$, compared to control value.
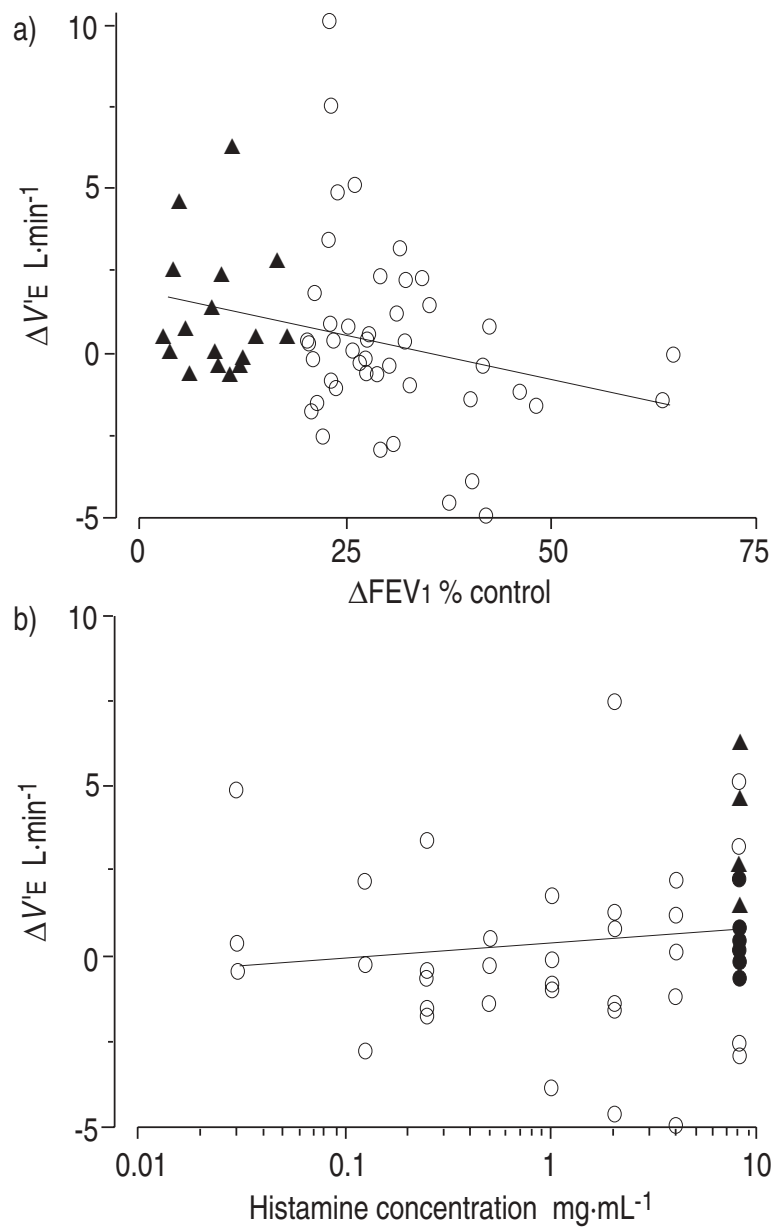

Fig. 2. - a) Relationship between change in minute ventilation $\left(\Delta V^{\prime} \mathrm{E}\right)$ and change in forced expiratory volume in one second $(\triangle \mathrm{FEV} 1)$ in response to histamine in 44 subjects with hyperresponsiveness (BHR+) and 19 subjects without hyperresponsiveness (BHR-). $\triangle F E V_{1}$ is expressed as percentage change from control values. For BHR+ $(\mathrm{r}=-0.319 ; \mathrm{p}<0.05)$; for BHR- $(\mathrm{r}=-0.012 ; \mathrm{p}=\mathrm{NS})$; for whole group $(\mathrm{r}=-$ $0.273 ; \mathrm{p}<0.05)$. b) Relationship between $\Delta V^{\prime} \mathrm{E}$ and histamine concentration in $44 \mathrm{BHR}+$ and $19 \mathrm{BHR}-$. For whole group $(\mathrm{r}=0.117 ; \mathrm{p}=\mathrm{NS})$. O: BHR+; $\boldsymbol{\Delta}$ : BHR-. NS: nonsignificant. 
Ventilatory responses to inhalation of histamine determined with the spirometer and by RIP were qualitatively and quantitatively the same, and, as a consequence, the data were pooled. Table 2 presents the results. $V^{\prime} \mathrm{E}$ increased significantly in BHR- as compared with control values before inhalation of histamine. The changes in $V^{\prime} \mathrm{E}$ were not significant in BHR+. Breathing frequency increased significantly in the whole group, BHR+ and BHR-. Although, on average, the control values of $f \mathrm{R}$ were higher in $\mathrm{BHR}+$, a further significant increase in $f \mathrm{R}$ was found in response to histamine. In the whole group, BHR+ and BHR-, no significant changes were found in $V \mathrm{~T}$ between control and histamine values. Both control values of $V \mathrm{~T}$ and $V \mathrm{~T}$ after histamine were significantly higher in BHR- as compared to BHR+. Meant SEM increase in FRC after inhalation of histamine was $0.26 \pm 0.03 \mathrm{~L}$, which was $8 \pm 1 \%$ of predicted. This increase in FRC was significantly $(\mathrm{p}<0.01)$ larger in $\mathrm{BHR}+$ than in BHR-.

Figure $2 \mathrm{a}$ and $\mathrm{b}$ shows the relationships between $\Delta V^{\prime} \mathrm{E}$ and $\Delta \mathrm{FEV} 1$ in response to histamine and between $\Delta V^{\prime} \mathrm{E}$ and the histamine concentration applied, respectively. Results are presented separately for BHR+ and BHR-. A significant correlation was found for the relationship between $\Delta V^{\prime} \mathrm{E}$ and $\Delta \mathrm{FEV} 1$ for $\mathrm{BHR}+(\mathrm{r}=-0.319$; $\mathrm{p}<0.05)$ and for the whole group $(\mathrm{r}=-0.273 ; \mathrm{p}<0.05)$, but not for BHR-. Thus, it appeared that the subjects with the largest decrease in $V^{\prime} E$ showed a relatively large decrease in FEV1. No significant relationship was found between $\Delta V^{\prime} \mathrm{E}$ and the histamine concentration applied.

\section{Discussion}

The changes in $V^{\prime} \mathrm{E}, f \mathrm{R}$ and $V \mathrm{~T}$ were not uniform; comparable numbers of subjects responded with increases $(\mathrm{n}=33)$ and decreases $(\mathrm{n}=30)$ in $V^{\prime} \mathrm{E}$. For $f \mathrm{R}, 40$ subjects responded with an increase and 23 with a decrease; and for $V \mathrm{~T}$, these numbers were 26 and 37, respectively. These results are in agreement with the observations of Stromberg and GustafsSon [13], who found that 50\% of their subjects responded to histamine with an increase in $V^{\prime} \mathrm{E}$ whereas, in the other $50 \% V^{\prime} \mathrm{E}$ was unchanged or tended to decrease.

The use of a mouthpiece and noseclip may be criticized. Effects of a mouthpiece on breathing pattern have been described in the literature but conclusions are not consistent [3]. In the present study, we have evaluated the effects of inhalation of histamine on respiratory variables. Values after histamine were compared to control values; i.e. before the start of histamine nebulization. Thus, baseline values were obtained after subjects had been connected to the mouthpiece and the nose had been clipped. Hence, the differences in breathing pattern found in response to histamine cannot be attributed to an effect of the mouthpiece or noseclip. It has recently been reported that ventilatory responses (i.e. $\left.V^{\prime} \mathrm{E}\right)$ to inhaled histamine, measured by RIP, were diminished when breathing through a mouthpiece whilst wearing a noseclip [13]. All of our subjects breathed through a mouthpiece with the nose clipped. This might explain why we found a considerable number of ventilatory nonresponders. If changes in breathing pattern induced by inhalation of histamine are masked by an effect of the mouthpiece and noseclip, responses in our study may be underestimated.

Histamine may stimulate RARs in two ways: mechanically (by histamine-induced bronchoconstriction) and chemically. In our previous studies in cats [20,21], we observed that stimulation of RARs either by negative airway pressure or by administration of histamine led to an increase in $f \mathrm{R}$. We think, therefore, that histamineinduced increases in $f \mathrm{R}$ seen in the present study (table 2) were due, at least in part, to a vagal reflex in which RARs are involved.

In the subjects who were $\mathrm{BHR}+$, the response of FRC on histamine was larger than in normal subjects (table 2 ). This can be attributed to the more pronounced airflow limitation and the possible presence of end-tidal inspiratory activity during increased activity of RARs $[20,21]$. An increase in FRC may limit an increase in $V \mathrm{~T}$ or even cause a decrease in $V \mathrm{~T}$ with a concomitant decrease in $V^{\prime}$ 'E. Moreover, the increased airway resistance after inhalation of histamine may cause a decrease in $V \mathrm{~T}$ and $V^{\prime} \mathrm{E}$ in subjects with large decreases in FEV1. This may explain: 1) why we found that $V^{\prime} E$ was negatively correlated to $\triangle \mathrm{FEV} 1$ (fig. 2), i.e. $V^{\prime} \mathrm{E}$ decreased especially in subjects with large decreases in FEV1 (BHR+); and 2) why the increase in $V^{\prime} \mathrm{E}$ after histamine was not significant in subjects who were hyperresponsive (table 2). A combination of histamine-induced increases in $f \mathrm{R}$ and bronchoconstriction-induced reductions in $V$ T may explain why, in several subjects $(n=24)$, opposite responses were seen, i.e. $f \mathrm{R}$ increased whilst simultaneously $V \mathrm{~T}$ decreased.

We conclude that, in general, respiratory responses to inhaled histamine are not predictable. Respiratory frequency increased significantly both in hyperresponsive and nonhyperresponsive subjects. The concomitant increase in minute ventilation, however, was significant in nonhyperresponsive subjects but not in hyperresponsive subjects. These findings may be interpreted to indicate that different mechanisms with opposite effects may be operating simultaneously, e.g. excitation of central inspiratory activity by stimulation of rapidly-adapting pulmonary stretch receptors, which will promote increases in respiratory frequency, tidal volume and minute ventilation, and bronchoconstriction with increased airway resistance, which will promote decreases in these parameters. As a consequence, depending on the net result of these opposite contributions to, for instance minute ventilation, administration of histamine will cause an increase in minute ventilation in one subject and a decrease in another subject.

\section{References}

1. McFadden ER, Lyons HA. Arterial blood gas tension in asthma. N Engl J Med 1968; 278: 1027-1032.

2. Woolcock AJ, Rebuck AS, Cade JF, Read J. Lung volume changes in asthma measured concurrently by two methods. Am Rev Respir Dis 1971; 104: 703-709.

3. Kassabian J, Miller KD, Lavietes MH. Respiratory center output and ventilatory timing with acute airway (asthma) and alveolar (pneumonia) disease. Chest 1982; 81: 536-543.

4. Williams MH Jr. Asthma: the pulse is not the paradox. Lung 1991; 168: 179-184. 
5. Kesten S, Maleki-Yazdi MR, Sanders BR, et al. Respiratory rate during acute asthma. Chest 1990; 97: 58-62.

6. Chadha TS, Schneider AW, Birch S, Jenouri G, Sackner MA. Breathing pattern during induced bronchoconstriction. J Appl Physiol: Respirat Environ Exercise Physiol 1984; 56: 1053-1059.

7. Kelsen SG, Prestel TF, Cherniack NS, Chester EH, Deal EC Jr. Comparison of the respiratory responses to external resistive loading and bronchoconstriction. J Clin Invest 1981; 67: 1761-1768.

8. Savoy J, Louis M, Kryger MH, Forster A. Respiratory response to histamine- and methacholine-induced bronchospasm in nonsmokers and asymptomatic smokers. Eur Respir J 1988; 1: 209-216.

9. Oliven A, Cherniack NS, Deal EC, Kelsen SG. The effects of acute bronchoconstriction on respiratory activity in patients with chronic obstructive pulmonary disease. Am Rev Respir Dis 1985; 131: 236-241.

10. Woolcock AJ. Asthma: What are the important experiments? Am Rev Respir Dis 1988; 138: 730-744.

11. Lougheed MD, Lam M, Forkert L, Webb A, O'Donnell DE. Breathlessness during acute bronchoconstriction in asthma: pathophysiologic mechanisms. Am Rev Respir Dis 1993; 148: 1452-1459.

12. Savoy J, Fleetham JA, Arnup M-E, Anthonisen NR Airway anesthesia and respiratory response to methacholine-induced bronchoconstriction. Respir Physiol 1981; 43: 59-68.

13. Stromberg NOT Gustafsson PM. Ventilatory pattern during bronchial histamine challenge in asthmatics. Eur Respir J 1993; 6: 1126-1131.

14. Fanelli A, Duranti R, Gorini M, Spinelli A, Gigliotti F, Scano G. Histamine-induced changes in breathing pattern may precede bronchoconstriction in selected patients with bronchial asthma. Thorax 1994; 49: 639-643.

15. Millman RP, Silage DA, Peterson DD, Pack AI. Effect of aerosolized histamine on occlusion pressure and ventilation in humans. J Appl Physiol: Respirat Environ Exercise Physiol 1982; 53: 690-697.

16. Savoy J, Allgower E, Courteheuse C, Junod AF. Ventilatory response to bronchospasm induced by methacholine and histamine in man. Respir Physiol 1984; 56: 195-203.

17. Armstrong DJ, Luck JC. A comparative study of irritant and type J receptors in the cat. Respir Physiol 1974; 21: 47-60.

18. Coleridge HM, Coleridge JCG. Reflexes evoked from tracheobronchial tree and lungs. In: Cherniack NS, Widdicombe JG, eds. Handbook of Physiology. The Respiratory System. Control of Breathing. Vol. II. Bethesda, MD, American Physiological Society, 1986; pp. 395-429.
19. Davies A, Roumy M. A role of pulmonary rapidlyadapting receptors in control of breathing. Aust J Exp Biol Med Sci 1986; 64: 67-78.

20. Meessen NEL, van der Grinten CPM, Folgering HTM, Luijendijk SCM. Histamine-induced end-tidal inspiratory activity and lung receptors in cats. Eur Respir $J$ 1995; 8: 2094-2103.

21. Meessen NEL, van der Grinten CPM, Folgering HTM, Luijendijk SCM. Tonic activity in inspiratory muscles during continuous negative airway pressure. Respir Physiol 1993; 92: 151-166.

22. White MV, Kaliner MA. Regulation by histamine. In: Crystal RG, West JB, Barnes PJ, Cherniack NS, Weibel ER, eds. The Lung: Scientific Foundations. New York, Raven Press, 1991; pp. 927-939.

23. Dixon M, Jackson DM, Richards IM. The effects of H1 and $\mathrm{H} 2$ receptor agonists and antagonists on total lung resistance, dynamic lung compliance and irritant receptor discharge in the anaesthetized dog. Br J Pharmacol 1979; 66: 203-209.

24. Vidruk EH, Hahn HL, Nadel JA, Sampson SR. Mechanisms by which histamine stimulates rapidly-adapting receptors in dog lungs. J Appl Physiol: Respirat Environ Exercise Physiol 1977; 43: 397-402.

25. Sellick H, Widdicombe JG. Stimulation of lung irritant receptors by cigarette smoke, carbon dust, and histamine aerosol. J Appl Physiol: Respirat Environ Exercise Physiol 1971; 31: 15-19.

26. Meessen NEL, van der Grinten CPM, Luijendijk SCM, Folgering HTM. Histamine-induced bronchoconstriction and end-tidal inspiratory activity in man. Thorax 1996; 51: 1192-1198.

27. Cockcroft DW, Killian DN, Mellon JJA, Hargreave FE. Bronchial reactivity to inhaled histamine: a method and clinical survey. Clin Allergy 1977; 7: 235-243.

28. Quanjer PhH (ed). Standardized lung function testing. Report Working Party "Standardization of Lung Function Tests". Bull Eur Physiopathol Respir 1983; 19 (Suppl.): 1-95.

29. Hargreave FE, Ryan G, Thomson NC, et al. Bronchial responsiveness to histamine or methacholine in asthma: measurement and clinical significance. J Allergy Clin Immunol 1981; 68: 347-355.

30. Sterk PJ, Fabbri LM, Quanjer $\mathrm{PhH}$, et al. Airway responsiveness: standardized challenge testing with pharmacological, physical and sensitizing stimuli in adults. Eur Respir J 1993; 6: S53-S83.

31. Quanjer PhH, Tammelin GJ, Cotes JE, Pedersen OF, Peslin R, Yernault J-C. Lung volumes and forced ventilatory flows. Report Working Party "Standardization of Lung Function Tests". European Coal and Steel Community. Eur Respir J 1993; 9, Suppl. 16: 5-40. 